\title{
Economic and Environmental Analysis of Pellets' Production in Rio Pardo Watershed, Brazil
}

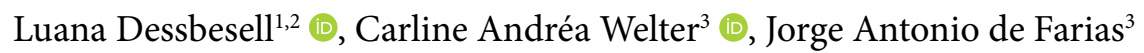 \\ ${ }^{1}$ Lakehead University, Thunder Bay, Ontario, Canada \\ ${ }^{2}$ Western University, London, Ontario, Canada \\ ${ }^{3}$ Universidade Federal de Santa Maria (UFSM), Santa Maria, RS, Brasil
}

\begin{abstract}
Economic and environmental aspects of residues energetic use in Brazil are extremelly important. In one hand, the country is today a recognized bioenergy producer in a global scenario; on the other, it is still struggling to provide a reliable renewable energy supply to rural communities. Local demand could be supplied through small investments using local forest mill residues as feedstock to produce value-add bio-based energy fuels. Therefore, this work aims at evaluating wood pellets production as an alternative source for supplying regional heat demand for drying grains and tobacco in the Rio Pardo Watershed (RPW), Brazil. It presents techno-economic analysis and risk assessment for a pellet plant supplied by sawmill residues available at the RPW. The results showed the economic feasibility of pellets production in the RPW. The pellets can be a clean, renewable alternative energy source to firewood for supplying farms demand for drying grains and tobacco.
\end{abstract}

Keywords: forest residues, bioenergy, forestry economics, crops drying. 


\section{INTRODUCTION AND OBJECTIVES}

Forests are recognized as a fundamental part of the carbon cycle and have been the focus of initiatives to reduce greenhouse gas (GHG) emissions. Thanks to the advent of technologies, such as pellets, wood residues will probably be one of the most important sources of biomass used to produce energy (heat, power and fuels), allowing the production of clean and efficient energy bioproducts from forest residues (Burden, 2012).

Biomass as raw material to generate bioenergy is of outstanding value. Not only because it is a renewable source, but also because it creates additional income and jobs in agricultural communities (Müller et al., 2005). Brazil is recognized as an emerging pellet producer and consumer, being part of the top 30 largest pellets' producers in the world scenario; however, its internal pellets consumption is still small, 75,000 t/year (Thrän et al., 2017). The country had around 18 industrial pellet plants in 2013, of which 13 operating and most of them working below capacity (50\%) (Abipel, 2014). Still, the new plant projects are focusing on exporting rather than supplying local energy needs.

Bioenergy has the potential to benefit farming communities in Brazil while bringing sustainability to agricultural activities. However, there is a lack of studies focusing on the feasibility of pellets production to supply the local communities energy demand.

A community that could benefit from pellets production is the Rio Pardo Watershed (RPW), a region formed mainly of tobacco farmers; which consume more than one billion stacked meters of firewood per crop season (Farias et al., 2017). The region is facing a firewood shortage, where about $50 \%$ of the farmers need to purchase firewood from long distances, which is more expensive and results in extra GHG emissions from transportation (Farias, 2013). Besides economic and environmental impacts, the current situation has social consequences as well; it results in more farmers leaving the rural areas inflating the cities with an untrained workforce.

In one hand, the RPW is facing firewood supply shortage; on the other, there is an excess of sawdust produced at the local sawmills with no established market. Furthermore, it has become an environmental issue because of storage limitations at the sawmills. In 2012, the province environmental regulation office released that there are 107 sawmills registered in the RPW (Rio Grande do Sul, 2013). According to Couto et al. (2004), approximately $50 \%$ of the sawn lumber volume produced in small and medium-size mills became residues, such as sawdust, sideboard and shavings.

Therefore, it is clear the opportunity to evaluate pellets production as an alternative to supply farmers' energy demand in the RPW. This paper aims to provide valuable decision-making information considering environmental and economic perspectives towards energy sources alternatives to supply the energy demand in the RPW. Moreover, we perform a risk assessment through a Monte Carlo simulation to model the uncertainties in market price, capital and feedstock costs.

\section{MATERIALS AND METHODS}

\subsection{Study region}

The RWP is located in south of Brazil, in the state of Rio Grande do Sul (RS). The area is geographically located at coordinates $28^{\circ} 50^{\prime}$ to $30^{\circ} 00^{\prime}$ of South latitude and $52^{\circ} 15^{\prime}$ to $53^{\circ} 00^{\prime}$ of west longitude. The watershed area is 3,636.79 square kilometers, which is constituted of 13 municipalities. The region natural forest formation is the Seasonal Deciduous Forest, integrating the Atlantic Rainforest biome (Marcuzzo et al., 1998).

\subsection{Sawmill residues}

The sawdust amount available in the RPW was retrieved from literature and government data. The following procedure was employed to estimate the amount of sawdust available for pellets production: the total number of sawmills (Rio Grande do Sul, 2013) multiplied by the average wood volume sawn by the sawmill in tonnes per day (Farias, 2017) multiplied by a sawdust yield factor (Brand, 2010). Twenty-one working days per month were considered to define the amount of sawdust available.

Moisture and high heating value (HHV) are crucial characteristics when considering biomass as raw material to produce pellets. Therefore, five random samples were collected and evaluated to obtain the HHV and moisture at Laboratório de Ensaios em 
Combustíveis da Fundação de Ciência e Tecnologia, located in Porto Alegre, RS, Brazil. The analysis of the moisture followed the NBR 14660 (ABNT, 2004) and the HHV followed the D5865 (ASTM, 2010).

Around $84.6 \%$ of the sawn lumber in the region comes from plantations of Eucalyptus species (Farias, 2017); consequently, it was assumed that the sawdust is predominantly Eucalyptus sp. It is also important to emphasize that sawmills at the study region run using wood assortments from planted forests, maintaining the native forests preserved (Farias, 2017).

\subsection{Economic assessment}

The amount of sawdust available and its moisture were used to define production capacity and equipment size and cost. Edifications costs, operation hours, labor, electricity consumption, line production losses and maintenance were acquired from personal communications with technicians of the equipment supplier Lippel, located in Agrolândia, in Santa Catarina (SC) state, Brazil.

The sawdust delivered cost at the mill gate was assumed to be the sawdust price traditionally applied to plywood market in Rio Grande do Sul ( $\mathrm{R} \$ 50.00$ per tonne delivered). The pellets price used to calculate the deterministic cash flow before taxes was assumed at $R \$ 346.66 / t$. The pellets price free on board varied from $\mathrm{R} \$ 480.00$ to $\mathrm{R} \$ 600.00 / \mathrm{t}$, in the Brazilian market (Garcia et al., 2016); therefore, it is reasonable to have a price below $\mathrm{R} \$ 480.00 / \mathrm{t}$ at the plant gate.

\subsection{Economic metrics}

The investment criteria calculated were: net present value (NPV) (equation 1), which represents the current return on the investment according to its duration (Rezende \& Oliveira, 2001); internal rate of return (IRR) (equation 2), which denotes a discount rate that results in a zero NPV (Silva et al., 2007); average cost (AC) (equation 3), which is a result of the division between net production and costs in the horizon period (Silva et al., 2007); and finally, the break-even point (BEP) (equation 4), it is a number of sales which results in an equal amount of revenues and costs; therefore, there is no profit or debt at the BEP (Dias, 1992). The Microsoft Excel ${ }^{\natural}$ was used for all calculations.
$N P V=\sum_{t=0}^{n} \frac{R_{t}}{(1+i)^{t}}$

NPV: net present value; $R_{t}$ net cash flow at time $t$ in years; $n$ : total number of periods $t$; i: discount rate.

$\sum_{t=0}^{n} R V(1+I R R)^{-t}=\sum_{j=0}^{n} C_{t}(1+I R R)^{-t}$

IRR: internal rate of return; $R_{t}$ : revenues at time $t$ in years; $C_{t}$ : costs at time $t$ in years; $n$ : total number of periods $t$.

$A C=\frac{\sum_{t=0}^{n} C_{t}(1+i)^{-t}}{\sum_{t=0}^{n} P T_{t}(1+i)^{-t}}$

AC: average cost; Ct: net costs value at time $t$; PTt: net production value at time $t$; $i$ : discount rate; $t$ : time in year " $n$ ".

$B E P_{(u)}=C F \div M C$

$\mathrm{BEP}_{(\mathrm{u})}$ : break-even point in units; MC: contribution margin defined by unitary price minus variable unitary cost; CF: fixed unitary costs.

The discount rate used was $10.9 \%$ corresponding to Brazilian Selic rate (Special System for Settlement and Custody) verified in September 2014 (Banco Central do Brasil, 2014). This rate is formed by the inflation index plus a remuneration rate.

Part of the biomass consumed supplies the pellets plant's drying system; therefore, after drying the sawdust, the plant capacity is $6 \mathrm{t} / \mathrm{h}$ of biomass at $10 \%$ moisture, according to Lippel technicians. Taking into account 2,016 operating hours per year and $3 \%$ of production losses, the estimated pellets production is $11,733.12 \mathrm{t} /$ year, considering half production in the first semester due to plant installation and workforce training.

This analysis does not consider commercialization and marketing costs. Pellets selling price considered was $\mathrm{R} \$ 346.66 / \mathrm{t}$. Equipment depreciation rate was $10 \%$ and $2.5 \%$ for buildings; residual value was not contemplated. The fixed costs are the plant, site, administrative labor, maintenance, opportunity cost and depreciation. The variable cost contains operational workforce, electricity and raw material. A cash flow diagram is presented in Figure 1.

An NPV sensitive and risk analysis were performed through a Monte Carlo Simulation to deal with the uncertainties surrounding the investment. A variation of $\pm 25 \%$ in all parameters was assumed following a triangular distribution due to a lack of 


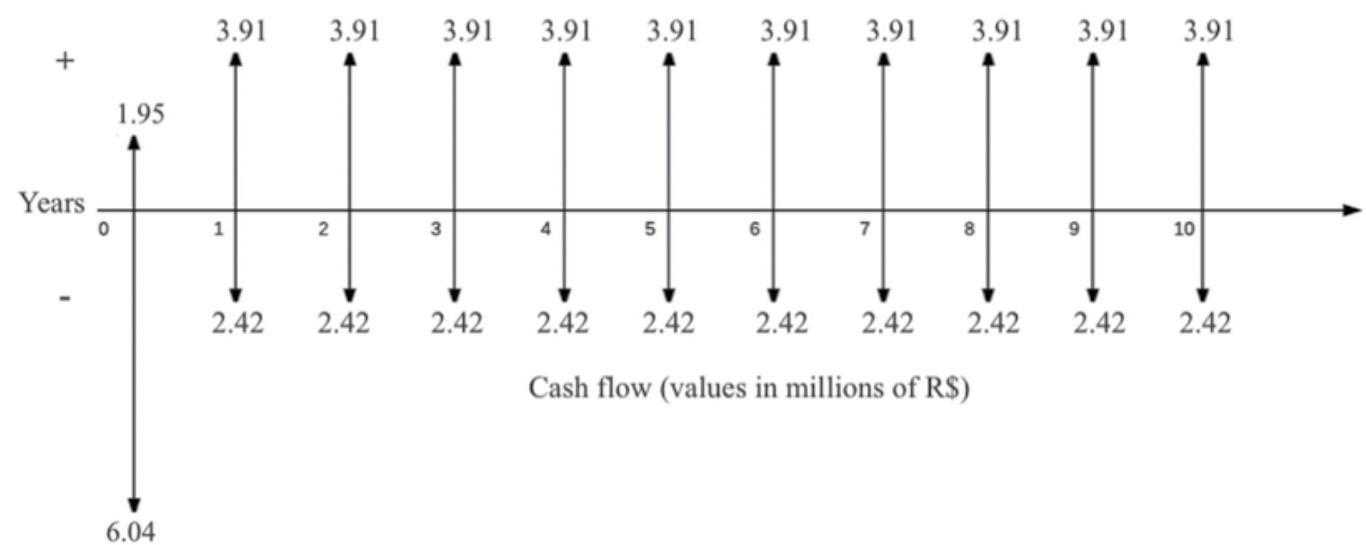

Figure 1. Pellet plant cash flow.

historical data to explore price fluctuations and cost behavior. The parameters analyzed were the capital cost ( $R \$ 5,053,456.17)$, selling price ( $R$ \$ 346.66/t) and raw material cost (sawdust $\mathrm{R} \$ 50.00 / \mathrm{t}$ and wood chips $\mathrm{R} \$ 40.00 / \mathrm{t}$ ); varying randomly in 10,000 runs according to the probability distribution. The simulation was executed in the Excel Analytic Solver Platform V2016-R3 (16.5.1.0) for Education, Copyright $\odot 2016$ Frontline Systems, Inc.

\section{RESULTS AND DISCUSSION}

\subsection{Economic analysis}

Around $69.92 \mathrm{t} /$ day of sawdust are available in the study region with a moisture of $32.62 \%$, which requires drying to reduce to $10 \%$ - standard moisture required for pellets production. The sawdust $\mathrm{HHV}$ was $4,655 \mathrm{kcal} / \mathrm{kg}$, which is common in the Eucalyptus species cultivated in the south of Brazil. Likewise, Quirino et al. (2004) evaluated 15 species of Eucalyptus and observed an average $\mathrm{HHV}$ of $4,874 \mathrm{kcal} / \mathrm{kg}$ varying between $5,023 \mathrm{kcal} / \mathrm{kg}$ and $4,217 \mathrm{kcal} / \mathrm{kg}$.

Based on premises presented in the methodology section, pellets production in the RPW is economically feasible, achieving an NPV of R $\$ 6.02 \mathrm{M}$ (millions), and an IRR of $43.1 \%$, higher than the discount rate used $10.9 \%$. These results provide decision-making input for prospective investors to analyze the investment according to rates available on the financial market and governmental funding programs. Also, it could be an opportunity to regional entrepreneurs, such as cooperatives, to invest in it.
Pellets production has shown economic growth potencial in Brazil (ABIB, 2016). In the case study presented here the $\mathrm{BEP}(\mathrm{u})$ was 5,444.15 t/year, which means that revenue is equal to total cost at this production level. Therefore, in the current production of $11,733.12 \mathrm{t} /$ year the plant is working $54 \%$ above the $\mathrm{BEP}(\mathrm{u})$. The $\mathrm{AC}$ cost calculated in this study was $\mathrm{R} \$ 153.77 / \mathrm{t}$ of pellets at the plant. According to the latest EIA Bioenergy repport, the pellets production in Brazil averaged at $€ 108.00 / t$ (Thrän et al., 2017); around $\mathrm{R} \$ 370.00 / \mathrm{t}$ considering an exchange rate for December 2016. This high production cost in Brazil is mostly due to the small scale and low efficiency of the exisiting plants, which are working on average at only $50 \%$ their production capacity (Thrän et al., 2017);

Considering operational costs, the AC breakdown was as follows: raw material (48\%) followed by depreciation (22\%), electricity (19\%), labor (6\%) and maintenance (5\%). Since electricity was found to be one of the most representative costs, an alternative could be the use of biomass to generate plant's required electricity and heat, although it is necessary to analyze feasibility and raw material supply availability to produce energy at the plant. The raw material is the most representative cost for pellets production. Couto et al. (2004) states that the most common cost structure is characterized for raw material (27\%); then commercialization (27\%); loan (20\%); labor (14\%); electricity (5\%); administration (5\%); and reposition equipment or depreciation (5\%).

As a preliminary conclusion, the economic analysis results show a favorable investment opportunity; however, there are limitations to be considered: 
- Raw material supply reliability: for this study, average values of monthly sawdust production were considered; however, a seasonality of residues production is expected in the sawmills according to their products demand. Additionally, other residues available in the region can also be used to produce pellets.

- Market: there may be a cultural and economic barrier for pellets usage in the Rio Pardo Watershed, once they have not been introduced to the community, and there are investments necessary to adapt their current drying system enabling pellets use.

- Pellets required standards: a detailed analysis of the pellets properties produced is necessary to ensure meeting required standards for commercialization.

\subsection{Sensitivity and risk analysis}

The Monte Carlo simulation results are presented in Figure 2. After 10,000 runs varying the capital cost, selling price and raw material cost, the most likely NPV was $\mathrm{R} \$ 6.02 \mathrm{M}$, the minimum was $\mathrm{R} \$-2.2 \mathrm{M}$ and the maximum R\$13.6 M. The investment has a low risk of presenting a NPV below zero and the probability of having an attractive NPV (that is, higher than R\$3.0 M) is $84 \%$ (Figure 2).

A sensitivity analysis was also performed to understand what parameters have a higher impact on the feasibility (Figure 3 ). The pellets selling price has the biggest influence in the NPV. A decrease of $25 \%$ in the price results in an NPV of R $\$ 0.9 \mathrm{M}$ (85\% reduction of the most likely NPV). Secondly, the capital cost, where an increase of $25 \%$ in the capital investment results in a decrease of $15 \%$ in the NPV. The lowest impact was found for the raw materials, which presented as less than $3.5 \%$ in the results.

Market fluctuations can highly affect pellets feasibility production in the RPW. As of 2015, there was no pellets plant installed in the region, showing a market opportunity. However, the pellets usage in tobacco and grain drying has to be technically and economically evaluated, therefore, it is necessary to compare pellets, sawdust, and firewood energy consumption, not only cost.

\subsection{Potential environmental benefits of pellets usage in the RPW}

Firewood is the primary energy source for tobacco curing and grain drying at RPW; however, new technologies allowed sawdust and pellets usage as an energy source. The supply system (Figure 4) is an example of these technologies. In this system, farmers need to feed equipment dispenser with biomass (e.g. pellets or sawdust), then the furnace is supplied automatically, and it is controlled according to the temperature program selected. The biomass is

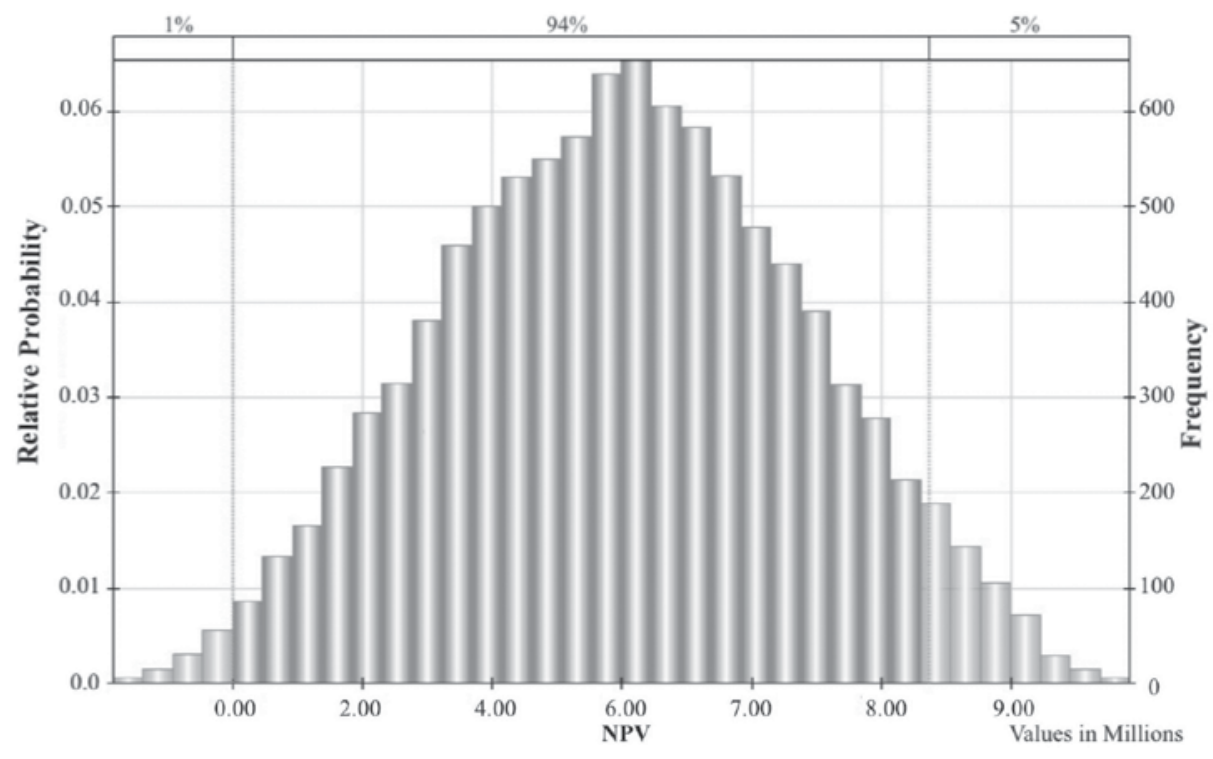

Figure 2. Monte Carlo results for NPV sensitivity. 


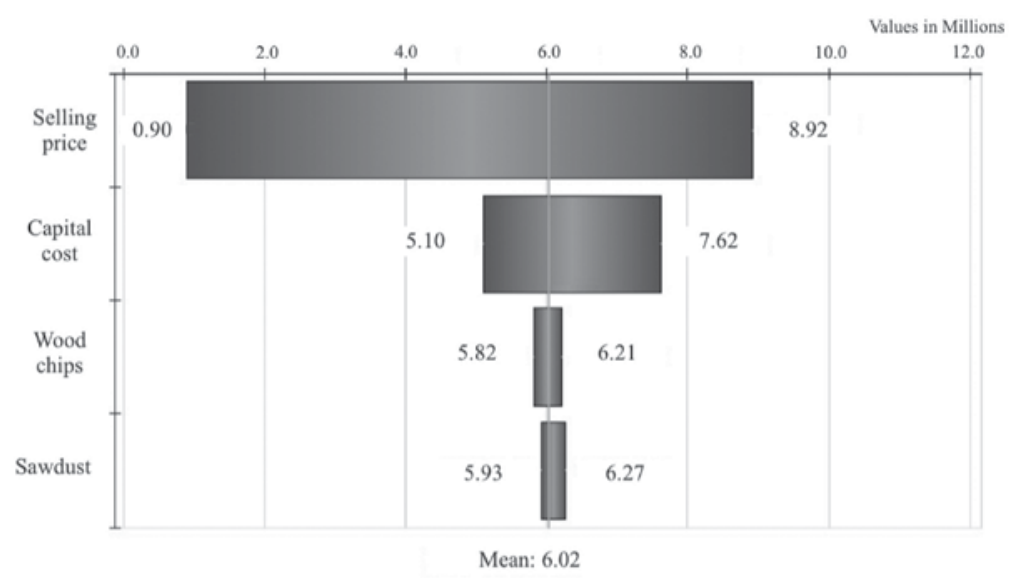

Figure 3. Sensitivity analysis of the NPV through Monte Carlo simulation.

conducted to the furnace by a screw conveyor and when the supply system dispenser is empty, a sonorous signal is emitted warning the farmer that the dispenser needs to be fed again.

Burning wood is considered carbon neutral for $\mathrm{CO}_{2}$ emissions because trees absorb and fix $\mathrm{CO}_{2}$ from the atmosphere during their grown; then when wood is used as a fuel source, it will release the absorbed $\mathrm{CO}_{2}$ back to the atmosphere. According to Middleton (2014), wood residues products usage as an energy source has lower environmental impact, since carbon cycle is closed with fewer atmosphere emissions.

In the RPW, it is common to observe sawdust stored in open areas due to a lack of sawmill infrastructure to place residues; as a result, gas emissions from natural wood decomposition can generate even more GHG

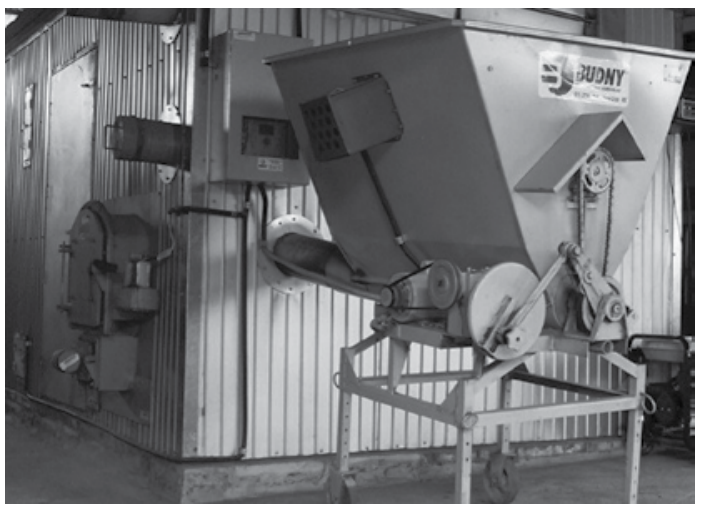

Figure 4. Supply system used in the Rio Pardo Watershed, Brazil. than burning wood (Foelkel, 2011). Residues such as sawdust, wood chips and bark, once stored in open areas, generate pollutants called volatile organic compounds (Granström, 2005). For example, methane emissions begin as soon as residues are stored in open areas; the anaerobic digestion, which occurs during the decomposition process, is responsible for $\mathrm{CO}_{2}$ and methane emissions (PCFplus, 2002).

The PCFplus (2002) developed a mathematical model to calculate methane emissions from wood residues (sawdust and bark) stored in open areas in Bulgaria. In their model, the amount of methane emitted is a result of the following variables: residues volume, carbon content, decomposition constant, hemicelluloses content and methane oxidation factor. The model estimated that each tonne of wood residues could generate $1.04 \mathrm{~m}^{3}$ of methane during the first year of decomposition.

Based on PCFplus (2002) model, it could be estimated that an amount of $1,524.87 \mathrm{~m}^{3}$ of methane can be generated from $1,466.22 \mathrm{t}$ of sawdust stored monthly in the 107 sawmills located at the RPW. It is important to point out that this estimative could vary according to temperature, and it tends to be greater in high-temperature regions, like the RPW.

In addition to decomposition emissions, the high moisture wood results in low combustion temperatures generating lower energetic efficiency and higher hydrocarbons and particulate emissions. Dried and compressed biofuels (e.g. pellets or briquettes) have low moisture and high density, thus, they present lower 
emissions during combustion and transportation. Wood harvesting and transportation to a distance of $400 \mathrm{~km}$ can achieve up to $50.3 \mathrm{~kg}$ of GHG emissions for each tonne of firewood (AGO, 2003).

Oliveira (2012) emphasized that $\mathrm{NO}_{\mathrm{x}}, \mathrm{SO}_{\mathrm{x}}$ and organic compounds emissions from pellets consumption are lower than other energy forms, such as firewood. Pellets combustion is more efficient and liberates less smoke because of the lower moisture. Moreover, Pa et al. (2013), while evaluating alternative heating energy sources in Canada, found that pellets could decrease down to $38 \%$ of $\mathrm{CO}_{2}$ emissions when replacing firewood. Especially because pellets have higher combustion efficiency which compensate pellets' production process emissions.

It is clear that wood pellets have higher potential to prevent GHG emissions when compared to other forms of wood for energy, such as firewood and sawdust. Raymer (2006) estimated that for each cubic meter of forest biomass used as bio-based fuel, the $\mathrm{CO}_{2} \mathrm{eq}\left(\mathrm{CO}_{2}\right.$ equivalent) emissions avoided vary between $0.21 \mathrm{t}$ to $0.63 \mathrm{t}$ depending on the replaced source. Considering Raymer's coefficient, it can be estimated that $18.11 \mathrm{~kg}$ of $\mathrm{CO}_{2}$ eq is avoided for each tonne of pellets used to replace firewood. Considering 11,733.12 $\mathrm{t}$ of pellets, it could avoid $212.05 \mathrm{t}$ of $\mathrm{CO}_{2}$ eq.

It is also important to state that the discussion provided in this section is purely theoretical, and emissions measurements are necessary to provide safe estimates comparing firewood and pellets in the Rio Pardo Watershed.

\section{CONCLUSIONS}

This paper provided an overall environmental and economic analysis for pellets production in the RPW, RS, Brazil. It was verified that pellets production is feasible (NPV 6.02 M, and IRR 43.1\%); however, pellets selling price strongly affects the project feasibility. Therefore, local pellets production from sawdust could be an alternative to managing the wood shortage in the RPW. Besides, there could also be environmental benefits from the lower GHG emissions generated if pellets replace firewood.

The results and risk analysis presented here bring the first step for introducing pellets as a source of energy to supply the RPW demand. Therefore, studies considering seasonality of raw material supply, live cycle assessment and market analyses comparing pellets with other available fuel sources are important to provide a complete scenario of pellets production in the region.

\section{SUBMISSION STATUS}

Received: 16 Sept., 2016

Accepted: 30 June, 2018

\section{CORRESPONDENCE TO}

\section{Luana Dessbesell}

Lakehead University, Faculty of Natural Resources Management, Braun Building, BB1007D, 955 Oliver Rd., P7B 5E, Thunder Bay, ON, Canada.

e-mail: luana.dessbesell@gmail.com

\section{FINANCIAL SUPPORT}

The authors thank Coordenacão de Aperfeiçoamento de Pessoal de Nível Superior (Capes) and Japan Tobacco International for the financial support.

\section{REFERENCES}

American Society for Testing and Materials - ASTM. D5865: standard test method for gross calorific value of coal and coke. West Conshohocken; 2010.

Associação Brasileira das Indústrias de Biomassa - ABIB. Case de sucesso empreendimento industrial de produção de pellets de madeira. 2016 Aug. 16 [cited 2018 June 12]. Available from: http://bit.ly/2HtAnn3

Associação Brasileira de Indústrias de Pellets - Abipel. Produtores de pellets: pellets map out 2014. 2014 [cited 2014 May 8]. Available from: https://bit.ly/2HU3dhV

Associação Brasileira de Normas Técnicas - ABNT. NBR 14660: madeira - amostragem e preparação para análise. Rio de Janeiro; 2004.

Australian Greenhouse Office - AGO. Life cycle assessment of greenhouse gas emissions from domestic wood heating. 2003 [cited 2014 May 15]. Available from: http://bit. ly/2HIcOan

Banco Central do Brasil. Dados diários. 2014 [cited 2014 Sept. 14]. Available from: http://bit.ly/2QaH3dQ

Brand MA. Energia de biomassa florestal. São Paulo: Interciência; 2010.

Burden D. Sawdust profile. 2012 [cited 2014 Aug. 20]. Available from: https://bit.ly/2XoOxwu 
Couto L, Muller MD, Silva AG Jr, Conde LJN. Produção de pellets de madeira: o caso da Bio Energy no Espírito Santo. Biomassa \& Energia 2004 [cited 2019 May 16]; 1(1): 45-52. Available from: http://bit.ly/2VN6jwR

Dias IP. Algumas observações sobre a margem de contribuição. Revista de Administração de Empresas 1992, 32(3): 36-45. 10.1590/S0034-75901992000300005

Farias JA. Rastreabilidade do componente florestal na cultura do tabaco. Santa Maria: Universidade Federal de Santa Maria; 2013.

Farias JA, Schneider PR, Biali LJ. Diagnóstico das florestas plantadas na bacia hidrográfica do Rio Pardo - RS. Ciência Florestal 2017, 27(1): 339-354. 10.5902/1980509826472

Foelkel C. Utilização dos conceitos da ecoeficiência na gestão das emissões atmosféricas do processo de fabricação de celulose kraft de eucalipto. In: Associação Brasileira Técnica de Celulose e Papel, editora. Eucalyptus online book. São Paulo; 2011 [cited 2014 Aug. 9]. Available from: http://bit.ly/30pAFE3

Garcia DP, Caraschi JC, Ventorim G, Vieira FHA. Trends and challenges of Brazilian pellets industry originated from agroforestry. Cerne 2016, 22(3): 233240. 10.1590/01047760201622032115

Granström K. Emissions of volatile organic compounds from wood [dissertation]. Karlstad: Karlstad University; 2005.

Marcuzzo S, Pagel SM, Chiappetti MIS. A reserva da biosfera da Mata Atlântica no Rio Grande do Sul: situação atual, ações e perspectivas. São Paulo: Conselho Nacional da Reserva da Biosfera da Mata Atlântica; 1998.

Middleton D. Hardwood vs. softwood. 2014 [cited 2014 May 1]. Available from: http://bit.ly/2YyuY4R

Müller MD, Couto L, Leite HG, Brito JO. Biomass and energy yield evaluation of a eucalypt clone, established at different planting densities. Biomassa \& Energia 2005, 2(3): 177-186.

Oliveira CM. Wood pellets Brasil. Itu: Associação Brasileira das Indústrias de Biomassa e Energia; 2012.

Pa A, Bi XT, Sokhansanj S. Evaluation of wood pellet application for residential heating in British Columbia based on a streamlined life cycle analysis. Biomass and Bioenergy 2013, 49: 109-122. 10.1016/j. biombioe.2012.11.009

PCFplus. Methane and nitrous oxide emissions from biomass waste stockpiles. 2002 [cited 2014 Feb. 12]. Available from: http://bit.ly/2Vz1x0Y

Quirino WF, Vale AT, Andrade APA. Calorific value of wood and wood residues. Biomassa \& Energia 2004, 1(2): 173-182.

Raymer AKP. A comparison of avoided greenhouse gas emissions when using different kinds of wood energy. Biomass \& Bioenergy 2006, 30(7): 605-617. 10.1016/j. biombioe.2006.01.009

Rezende JLP, Oliveira AD. Análise econômica e social de projetos florestais. Viçosa: Editora UFV; 2001.

Rio Grande do Sul. Relatório cadastral. Porto Alegre: Secretaria Estadual de Meio Ambiente; 2013.

Silva ML, Oliveira RJ, Valverde SR, Machado CC, Pires VAV. Cost and distance of reforestation wood transport for different types of trucks. Revista Árvore 2007; 31(6): 1073-1079. 10.1590/S0100-67622007000600012

Taylor BN, Thompson A, editors. The International System of Units (SI). Gaithersburg: National Institute of Standards and Technology; 2008. 10.6028/NIST. SP.330e2008

Thrän D, Peetz D, Schaubach K. Global wood pellet industry and trade study 2017. Paris: IEA Bioenergy; 2017. 